\title{
General Height-Diameter Equation Depending on the Stand Variables, for Eucalyptus benthamii
}

Saulo Jorge Téo ${ }^{1}$ (1)

Tainá Carnera da Silva ${ }^{1}$

\begin{abstract}
The aim of this study was to develop a general applicability equation to represent the hypsometric relationship of Eucalyptus benthamii Maiden et Cambage stands in Irani, Santa Catarina. The data came from a continuous forest inventory, with a simple random sampling design and the Bitterlich method. The functions to represent the hypsometric relationship were adjusted with their parameters linear function of stands variables, based on the Gauss-Newton algorithm. The models were evaluated according to the criteria of adjustment and precision, accuracy and validation. In general, the Harrison model, adjusted with the coefficient "c" linear function of age, dominant diameter and basal area, presented the best statistical performance to represent the hypsometric relationship of Eucalyptus benthamii.
\end{abstract}

Keywords: Height-diameter relationship, h-d relationship, eucalypt.

\section{INTRODUCTION AND OBJECTIVES}

In Brazil, the first Eucalyptus benthamii Maiden et. Cambage stands were planted in 1988 by EMBRAPA Florestas, in the municipality of Colombo, state of Paraná. The forest species aroused interest soon after its introduction in Brazil, due to its tolerance to low temperatures, good development, high growth rate and healthy appearance of the plants. (Alves et al., 2011).

Thus, in recent years, a considerable expansion in the areas of $E$. benthamii production has been verified in southern Brazil, especially in regions of frost occurrence. However, in spite of all the results presented by the species and the massive increase of plantation area, the main work carried out, until now, are basically related to its potential use in the pulp and paper industry (Müller et al., 2014).

Nevertheless, it is important to know the allometric relations of the species, among them the height-diameter relationship, which can provide technical directions to increase the productive potential of the species. It is extremely important to study the dendrometric variables of a forest, since they are used as the basis for appropriate silvicultural treatments in a forest stand, supporting forest management and planning.
The height measurement is a costly activity, generally making it impossible to obtain the height of all trees within a forest inventory plot. Based on the aforementioned, it is common to measure the diameter of all trees in the plot and the height of some, during forest inventory. Then, through height-diameter observations, mathematical functions must be adjusted and tested to estimate the heights of the non-measured trees. The use of these height-diameter equations reduces the cost of forest inventories (Ribeiro et al., 2010). Azevedo et al. (2011), reported that the use of height-diameter equations is of great practical significance and an important aspect to be considered in forest inventories.

The height-diameter relationship is susceptible to several factors, such as site quality (Retslaff et al., 2015; Vendruscolo et al., 2015), age (Machado et al., 2011; Paulo et al., 2011; Soares \& Tomé, 2002; Téo et al., 2017), stand density (Araújo et al., 2012; Silva et al., 2016; Téo et al., 2017), crown size (Machado et al., 2015), species (Azevedo et al., 2011; Donadoni et al., 2010; Hess et al., 2014; Sanquetta et al., 2013) and the sociological position of the trees (Costa et al., 2014; Leduc \& Goelz, 2009; Martins et al., 2016).

Retslaff et al. (2015) reported that the use of the variables dominant height and site index produced height-diameter

\footnotetext{
${ }^{1}$ Universidade do Oeste de Santa Catarina, Xanxere, SC, Brasil
} 
equations with more homogeneous and narrow residues distribution. The effect of stand density on the height-diameter relationship was evaluated by Silva et al. (2016), who found an accuracy reduction of the height estimates of Tectona grandis $L$. F., for wider spacings; similar results were found by Bartoszeck et al. (2004). Concerning the effect of the variables sociological position and crown length, Costa et al. (2014) and Machado et al. (2015) found height-diameter equations with better statistical performance fitted into sociological position and crown length classes, respectively.

In this context, it becomes imperative to select the most appropriate equation to estimate height in each forest stand, considering the large number of variables that effect the height-diameter relationship (Oliveira et al., 2011).

The height-diameter equations may have local or general applicability. Commonly, the local height-diameter equations are only dependent on tree diameter at breast height (d) and can only be applied to the stand where the data were gathered. On the other hand, the general or regional height-diameter equations are dependent on diameter at breast height and stand variables, such as age (t), dominant height (hdom) and stand density, developed for general application to a species or region (Soares \& Tomé, 2002).

In conducting the development of height-diameter equations of a Eucalyptus globulus Labill stand in Portugal, Tomé et al. (2007) recommended an equation with its parameters expressed as linear combination of dominant height (hdom), dominant diameter (ddom) and quadratic mean diameter (dg) of the forest stand as independent variables.

In Brazil, it is common to use empirical models to represent height-diameter relationship (Oliveira et al., 2011; Rufino et al., 2010). However, it is more appropriate to use theoretical models, which have an implicit hypothesis associated with the characteristics of the height-diameter relationship and considering the causes and effects of different variables on the height-diameter relationship (Téo et al., 2017).

Thus, this research aimed to develop general applicability height-diameter equations, with their parameters expressed as function of forest stand variables for Eucalyptus benthamii
Maiden et Cambage, in Irani, state of Santa Catarina, in order to indicate the one that best describes the height-diameter relationship.

\section{MATERIALS AND METHODS}

The present study was undertaken in a forest stand of Eucalyptus benthamii, located in the municipality of Irani, state of Santa Catarina, Brazil (Figure 1). According to Alvares et al. (2013), the study area presents an altitude of 887 $\mathrm{m}$ a.s.l., $\mathrm{Cfb}$ climate type based on the Köppen classification, that is, humid subtropical zone, oceanic climate, without a dry season and with temperate summers. The average annual temperature of the region is $16,6^{\circ} \mathrm{C}$, the average temperature of the hottest month is $20,7^{\circ} \mathrm{C}$ and the coldest month is $12,2^{\circ} \mathrm{C}$. The average annual relative humidity ranges from 76 and $78 \%$, the total annual precipitation is $1836 \mathrm{~mm}$, evenly distributed all year long. The main soil types in the region are Haplic Cambisols, Humic Cambisols, Litholic Neosol, Red Nitisol and Haplic Nitisol (EMBRAPA, 2011).

The forest stand of Eucalyptus benthamii has an area of 13,292 ha, initial spacing of 2,5 x 2,5 m, or 1600 plants per hectare. The forest stand was sampled by a continuous forest inventory with two phases, the first in June 2015 at 7,5 years of age and the second in June 2017 at 9,5 years of age. Twelve sampling units were measured in each occasion, distributed according to the unrestricted random design and using the Bitterlih sampling method. The sampling method was operationalized using the Criterion RD 1000, with the basal-area factor equal to 1 .

For each Eucalyptus benthamii tree counted by Bitterlih sampling method, were measures the following variables: i) circumference at breast height (c), directly with a metric tape, which were subsequently transformed in diameter and ii) total height (h) in meters, measured with TruPulse 200B hypsometer, at least ten trees per sampling unit.

After data collection, four models were adjusted and tested to represent the hypsometric relationship of Eucalyptus benthamii (Table 1). 


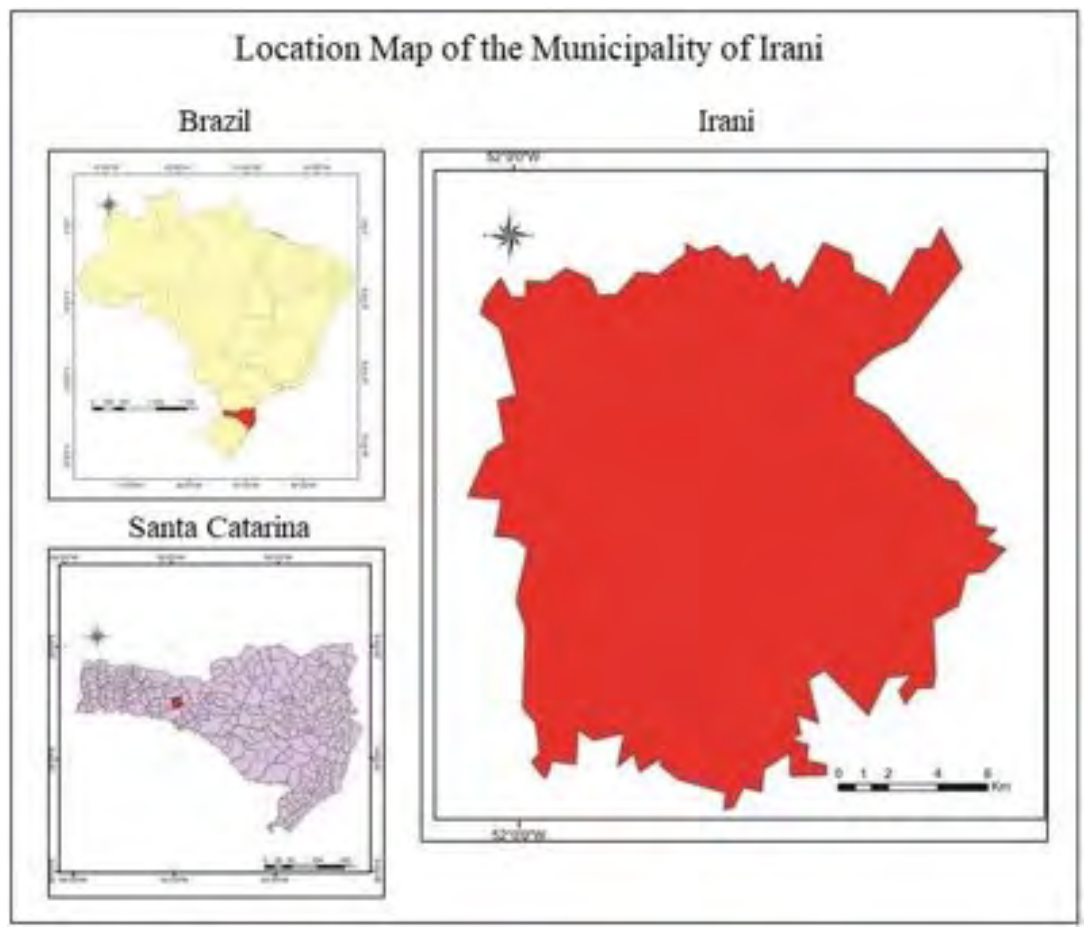

Figure 1. Location of the municipality of Irani in the state of Santa Catarina, Brazil.

Table 1. Candidate functions to model the height-diameter relationship of Eucalyptus benthamii Maiden et Cambage, in the municipality of Irani - SC.

$\begin{gathered}\text { n } \\ \text { Author } \\ 1 \quad \begin{array}{c}\text { Harrison } \\ \text { et al. } \\ (1986)\end{array}\end{gathered} \quad h=1,3+\left\{h_{\text {dom }}\left[1+a e^{\left(b h_{\text {dom }}\right)}\right]\left[1-e^{\left(-c\left(\frac{d}{h_{d o m}}\right)\right)}\right]\right\}$

Source: Adapted from Harrison et al. (1986) and Paulo \&Tomé (2009).

Where: $\mathrm{h}=$ total height $(\mathrm{m}) ; \mathrm{d}=$ diameter at breast height $(\mathrm{cm}) ; \mathrm{h}_{\mathrm{dom}}=$ dominant height $(\mathrm{m}) ; \mathrm{d}_{\mathrm{dom}}=$ dominant diameter $(\mathrm{cm}) ; \mathrm{e}=$ Euler's constant $(2,718281829 \ldots)$; $\mathrm{a}, \mathrm{b}, \mathrm{c}=$ parameters.

The candidate functions were adjusted with their parameters expressed as a linear function of different categories of stand variables. When the Harrison et al. (1986) model was adjusted with its parameter "a" expressed as a linear function of stand variables, it was denominated Harrison_a, when the adjustment was proceeded with its parameter " $b$ " expressed as linear function of stand variables, it was denominated Harrison_b, and finally, Harrison_c(Equation 1). The models by Michailoff, Prodan and Stoffels \& Van Soest have only one parameter "a" expressed as linear combination of stand variables, so they were denominated Michailoff_a, Prodan_a and Stoffels \& Van Soest_a.

$$
h=1,3+\left\{h_{\text {dom }}\left[1+a e^{\left(b h_{\text {dom }}\right)}\right]\left[1-e^{\left(-c\left(\frac{d}{h_{\text {dom }}}\right)\right)}\right]\right\}(\text { Equation 1) }
$$

in which: $a=a_{0}+a_{1} t+a_{2} d_{d o m}+a_{3} G$, or $b=b_{0}+b_{1} t+b_{2} d_{\text {dom }}+b_{3} G$, or $c=c_{0}+c_{1} t+c_{2} d_{\text {dom }}+c_{3} G ; \mathrm{h}=$ total height $(\mathrm{m}) ; \mathrm{d}=$ diameter at breast height $(\mathrm{cm}) ; \mathrm{h}_{\mathrm{dom}}=$ dominant height of the sample plot (m); a, b, c, a0, a1, a2, a3, b0, b1, b2, b3, c0, c1, c2, c3 = parameters; $\mathrm{t}=$ age of the forest stand (years); $\mathrm{d}_{\mathrm{dom}}=$ dominant diameter $(\mathrm{cm}) ; \mathrm{G}=$ basal area of the sample plot $\left(\mathrm{m}^{2}\right.$.ha- $\left.{ }^{1}\right)$; $\mathrm{e}=$ Euler's constant $(2,718281829 \ldots)$.

Firstly, the stand variables which the parameters of the height-diameter functions were expressed as linear combination (Equation 1), were organized into different categories: I) age; II) sample plot; III) stand density.

The first category was represented by age $(t)$ in years. The second category was represented by: mean diameter $\left(\mathrm{d}_{\text {mean }}\right)$, in $\mathrm{cm}$; dominant diameter $\left(\mathrm{d}_{\mathrm{dom}}\right)$, in $\mathrm{cm}$; coefficient of variation of the diameters $\left(\mathrm{CV}_{\mathrm{d}}\right)$, in \%; quadratic mean diameter $\left(\mathrm{d}_{\mathrm{g}}\right)$, in $\mathrm{cm}$, calculated according to Machado \& Figueiredo Filho (2014); maximum diameter of the sample 
plot $\left(\mathrm{d}_{\max }\right)$, in $\mathrm{cm}$; and dominant height $\left(\mathrm{h}_{\text {dom }}\right)$, in $\mathrm{m}$. The variables of the category stand density were: basal area $(G)$, in $\mathrm{m}^{2}$.ha $\mathrm{a}^{-1}$; number of trees $(\mathrm{N})$, trees.ha ${ }^{-1}$; the transformations of the number of trees N-1 and $100^{*} \mathrm{~N}-1$; and Wilson Factor (WF) (Equation 2) (Wilson, 1951).

$$
W F=\frac{100}{\sqrt{N}+h_{\text {dom }}}(\text { Equation 2) }
$$

in which: $\mathrm{N}=$ number of trees (trees.ha-1); $\mathrm{h}_{\mathrm{dom}}=$ dominant height $(\mathrm{m})$.

For each category of independent variables was applied the multiple linear regression, where total height (h) of the Eucalyptus benthamii trees was the dependent variable and the stand variables of each category was the regressor variables. The selection of the best regressor variable within each category was made with PROC REG procedure in the software program $S A S^{\circledast}$ University Edition, based on the rsquare variable selection method.

The linear combination of stand variables, presented in Equation 1 for each parameter, was based on linear multiple regression with the best stand variable of each category as regressor variables and again, the total height (h) as independent variable. For the final selection of the stand variables, we analyzed the significance of parameters (Student's value) and the variance inflation factor (VIF), to avoid collinearity, according to Myers (1986).

The candidate functions (Table 1) to represent the heightdiameter relationship were adjusted for 289 values of total height $(\mathrm{h})$ and diameter at breast height. The parameter estimation of the functions was made with PROC NLIN procedure in the software program SAS ${ }^{\circledast}$ University Edition, based on the Gauss-Newton iterative method. The studies of Harrison et al. (1986) and Téo et al. (2017) provided the basis to obtain the initial values of the parameters of the heightdiameter functions. The final estimates of the parameters of the height-diameter equations should exclude zero in its 95\% confidence band, indicating that there are only nonzero values for the parameters and then, they are always significant (Téo et al., 2017).

In the initial selection phase, the criteria for comparing the performance of the height-diameter equations were: adjusted coefficient of determination $\left(\mathrm{R}^{2}{ }_{\mathrm{ad}}\right)$ (Equation 3), standard error of estimate (syx\%) (Equation 4), mean of differences (MD) (Equation 5), mean of absolute differences (MAD) (Equation 6) and the analysis of studentized residuals $\left(r_{i}\right)$ (Equation 7).

$$
\begin{gathered}
R_{a d}^{2}=1-\left[\left(\frac{\sum_{i=1}^{n}\left(Y_{i}-\hat{Y}_{i}\right)^{2}}{\sum_{i=1}^{n}\left(Y_{i}-\bar{Y}_{i}\right)^{2}}\right) * \frac{(n-1)}{n-p}\right](\text { Equation 3) } \\
s y x \%=\frac{\frac{\sqrt{\sum_{i=1}^{n}\left(Y_{i}-\hat{Y}_{i}\right)^{2}}}{n-p}}{\bar{Y}} * 100 \text { (Equation 4) } \\
M D=\frac{\sum_{i=1}^{n}\left(Y_{i}-\widehat{Y}_{i}\right)}{n}(\text { Equation 5) } \\
M A D=\frac{\sum_{i=1}^{n}\left|Y_{i}-\hat{Y}_{i}\right|}{n}(\text { Equation 6) } \\
r_{i}=\frac{e_{i}}{s \sqrt{\left(1-h_{i i}\right)}}(\text { Equation 7) }
\end{gathered}
$$

in which: $Y_{i}=$ measured dependent variable for observation i (total height, in meters); $\hat{Y}_{i}=$ estimated dependent variable for observation i (total height, in meters); $\bar{Y}=$ mean of the measured dependent variable; $\mathrm{n}=$ number of observations; $\mathrm{p}=$ number of equation parameters; $\mathrm{e}_{\mathrm{i}}=\operatorname{error}$ or residual $\left(Y_{i}-\hat{Y}_{i}\right)$;

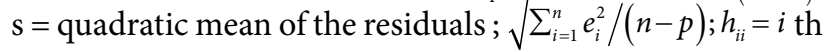
HAT matrix element.

The graphical analysis of the studentized residuals was performed on the estimated dependent variable $\left(\hat{Y}_{i}\right)$, which was aimed at the uniform distribution of residuals with absence of patterns. The verification of the heteroscedasticity was made by visual analysis of the distribution of studentized residuals, seeking to identify the funnel effect indicates that as the estimated dependent variable $\left(\hat{Y}_{i}\right)$ gets large, the deviations of the residuals from zero become greater (Myers, 1986; Draper \& Smith, 1998; Montgomery et al., 2006). Once heteroscedasticity of the distribution of studentized residuals of the equation resulting from the adjustment by the ordinary least squares method was detected, the weighted least squares method was adjusted. The weights tested included various transformations and combinations of stand density variables (basal area, in $\mathrm{m}^{2}$.ha ${ }^{-1}$; number of trees, in trees. $\mathrm{ha}^{-1}$ ) and sample plot variables (mean diameter, quadratic mean diameter, maximum diameter, dominant diameter, in $\mathrm{cm}$; coefficient of variation of the diameters, in \%), based on the protocol described by Parresol (1993), which assumes that the variance of the residuals is an exponential function of multiple explanatory variables of the model, as well as their transformations and combinations. To verify whether the studentized residuals had normal distribution or not, 
a graphical representation of these increasingly ordered values against the theoretical quantiles of the normal distribution was constructed. Once the non-normal distribution of the studentized residuals was verified, the weighted least squares method was adjusted, with weights assigned to the studentized residuals exceeding the interval \pm 2 , based on the method described by Huber (1964) and recommended by Myers (1986).

In addition to the statistics calculated by the residuals $\left(\mathrm{R}^{2}{ }_{\text {ad }}\right.$, syx\%, MD e MAD), the height-diameter equations were submitted to validation using PRESS residuals $\left(\mathrm{e}_{\mathrm{i}}{ }_{-\mathrm{i}}\right)$ (Equation 8). The PRESS residual of the observation $i$ is calculated by subtracting from the observed dependent variable $\left(\mathrm{Y}_{\mathrm{i}}\right)$ the value of the dependent variable estimated by the equation adjusted for the dataset without the observation $\mathrm{i}\left(\hat{Y}_{i,-i}\right)$. Consider a set of data in which the first observation was left aside from the sample, and the remaining " $n-1$ " observations were used to estimate the coefficients of the height-diameter model and obtain $\hat{Y}_{i,-i}$ for the first observation. The first observation is then replaced, and the second observation withheld with the coefficients estimated again and obtain $\hat{Y}_{i,-i}$ for the second observation. This procedure continued until all observations were removed one by one, and thus the model was adjusted "n" times (Myers, 1986).

$$
e_{i,-i}=Y_{i}-\hat{Y}_{i,-i}(\text { Equation } 8)
$$

in which: $e_{i}{ }_{-i}=$ PRESS residual for observation $i$; $Y_{i}=$ value of the dependent variable for observation $i$; $\hat{Y}_{i,-i}=$ dependent variable estimated by the model when adjusted without observation $\mathrm{i}$.

For the final selection of the height-diameter equation, via the PRESS residuals, the following validation statistics were calculated: modeling efficiency (EM) (Equation 9); average of the PRESS differences $\left(\mathrm{MAD}_{\text {PRESS }}\right.$ ) (Equation 10); average of the PRESS absolute differences $\left(\mathrm{MAD}_{\text {PRESS }}\right)$ (Equation 11); and the $5 \%$ and $95 \%$ percentile values of the PRESS residuals. The efficiency of modeling is a statistic that is analogous with the coefficient of determination and expresses the proportion of variance explained by the model. The average of PRESS differences indicates the bias of the model, whereas the average absolute PRESS differences indicates the accuracy. The $5 \%$ and $95 \%$ percentile values express the magnitude and symmetry of the distribution of PRESS residuals.

$$
E M=1-\left[\frac{\sum_{i=1}^{n}\left(Y_{i}-\hat{Y}_{i,-1}\right)^{2}}{\sum_{i=1}^{n}\left(Y_{i}-\bar{Y}_{i}\right)^{2}}\right](\text { Equation 9) }
$$

$$
\begin{gathered}
M D_{\text {PRESS }}=\frac{\sum_{i=1}^{n}\left(Y_{i}-\hat{Y}_{i,-i}\right)}{n}(\text { Equation 10) } \\
M A D_{\text {PRESS }}=\frac{\sum_{i=1}^{n}\left|Y_{i}-\hat{Y}_{i,-i}\right|}{n}(\text { Equation 11) }
\end{gathered}
$$

in which: $Y_{i}, \hat{Y}_{i,-1}, \bar{Y}, n=$ have been defined previously.

\section{RESULTS AND DISCUSSION}

All the models tested to represent the hypsometric relationship of Eucalyptus benthamii presented significant estimates of the parameters $(\alpha=0,05)$, in the way they are in Table 1.

The Harrison et al. (1986) model adjusted with its parameters expressed as a linear function of stand variables showed the best statistical performance to represent the height-diameter relationship of Eucalyptus benthamii (Table 2). Among the different versions of the Harrison et al. (1986) model, Harrison_b presented the best adjustment (R2ad), the smaller error (syx\%) and the value of MAD closer to zero, while Harrison_a and Harrison_c presented equal values of $\mathrm{R}^{2}{ }_{\text {ad }}$ and syx\%. The Harrison et al. (1986) with its parameter "c" expressed as a linear function of stand variables presented the bias (MD) closer to zero.

Similar to the results found in this study, Téo et al. (2017) reported the best statistical performance for Harrison et al. (1986) model adjusted with its parameters expressed as a linear function of stand variables, to represent the heightdiameter relationship of Pinus taeda L. in the Midwest region of Santa Catarina State, Brazil. The different versions of the Harrison et al. (1986) model, adjusted by Téo et al. (2017), also presented negative bias (MD).

The models by Michailoff, Prodan and Stoffels \& Van Soest, modified by Tomé (1988), showed similar statistical performance when compared to each other. However, when they were compared with the Harrison et al. (1986) model, they presented poorer adjustment $\left(\mathrm{R}_{\text {ad }}^{2}\right)$, greater error (syx \%) and bias (MD) (Table 2).

Table 2. Selection statistics of the equations to represent the hypsometric relationship of Eucalyptus benthamii Maiden et Cambage.

\begin{tabular}{lcccc}
\multicolumn{1}{c}{ Equation } & $\mathbf{R}^{2}$ ad & syx $\%$ & MD & MAD \\
\hline Harrison_a & 0,8408 & 8,82 & $-0,0146$ & 1,6429 \\
Harrison_b & 0,8441 & 8,73 & $-0,0155$ & 1,6222 \\
Harrison_c & 0,8408 & 8,82 & $-0,0125$ & 1,6586 \\
\hline Michailoff_a & 0,3697 & 17,55 & 2,1461 & 3,5167 \\
Prodan_a & 0,3818 & 17,38 & 2,1476 & 3,4282 \\
Stoffels \& Van Soest_a & 0,3342 & 18,04 & 2,1529 & 3,6014 \\
\hline
\end{tabular}

Where: $\mathrm{R}_{\text {ad }}^{2}=$ adjusted coefficient of determination; syx $\%=$ standard error of estimate; $\mathrm{MD}=$ mean of differences; $\mathrm{MAD}=$ mean of absolute differences. 
The Harrison et al. (1986) model adjusted with its parameters expressed as a linear function of stand variables, by ordinary least squares, produced distribution of studentized residuals without heteroscedasticity and without evidences of non-normality, then weighted least squares regression with Parresol (1993) and Huber (1964) methods were not necessary (Figure 2). Téo et al. (2017) reported studentized residuals without heteroscedasticity, but with evidences of non-normality of the residuals, especially with large residuals at both extremes of the distribution of errors for the Harrison et al. (1986) model.

The models by Michailoff, Prodan and Stoffels \& Van Soest adjusted with its parameters expressed as a linear function of stand variables, by ordinary least squares, produced distribution of studentized residuals without heteroscedasticity, however with characteristics of non-normality of the residuals, mainly at the negative values of the distribution of errors. The Michailoff, Prodan and Stoffels \& Van Soest equations tended to underestimate the predicted values of total height smaller than $20 \mathrm{~m}$. (Figure 3).

Similarly to what happened with the selection statistics, the Harrison et al. (1986) model adjusted with its parameters expressed as a linear function of stand variables, showed the best performance for validation statistics to height-diameter of Eucalyptus benthamii (Table 3). Among the different versions of the Harrison et al. (1986) model, Harrison_c presented the best performance for validation statistics, with superior modeling efficiency (EM) and values of $M D_{\text {PRESS }}$ and percentile values of the PRESS residuals closer to zero. However, Harrison_a presented the value of $\mathrm{MD}_{\text {PRESS }}$ closest to zero, which indicates the less biased equation. The Michailoff, Prodan and Stoffels \& Van Soest equations showed similar validation statistics between them, but always with less modeling efficiency (EM), less accuracy, more bias and less symmetry when compared with the different versions of the Harrison et al. (1986) model.
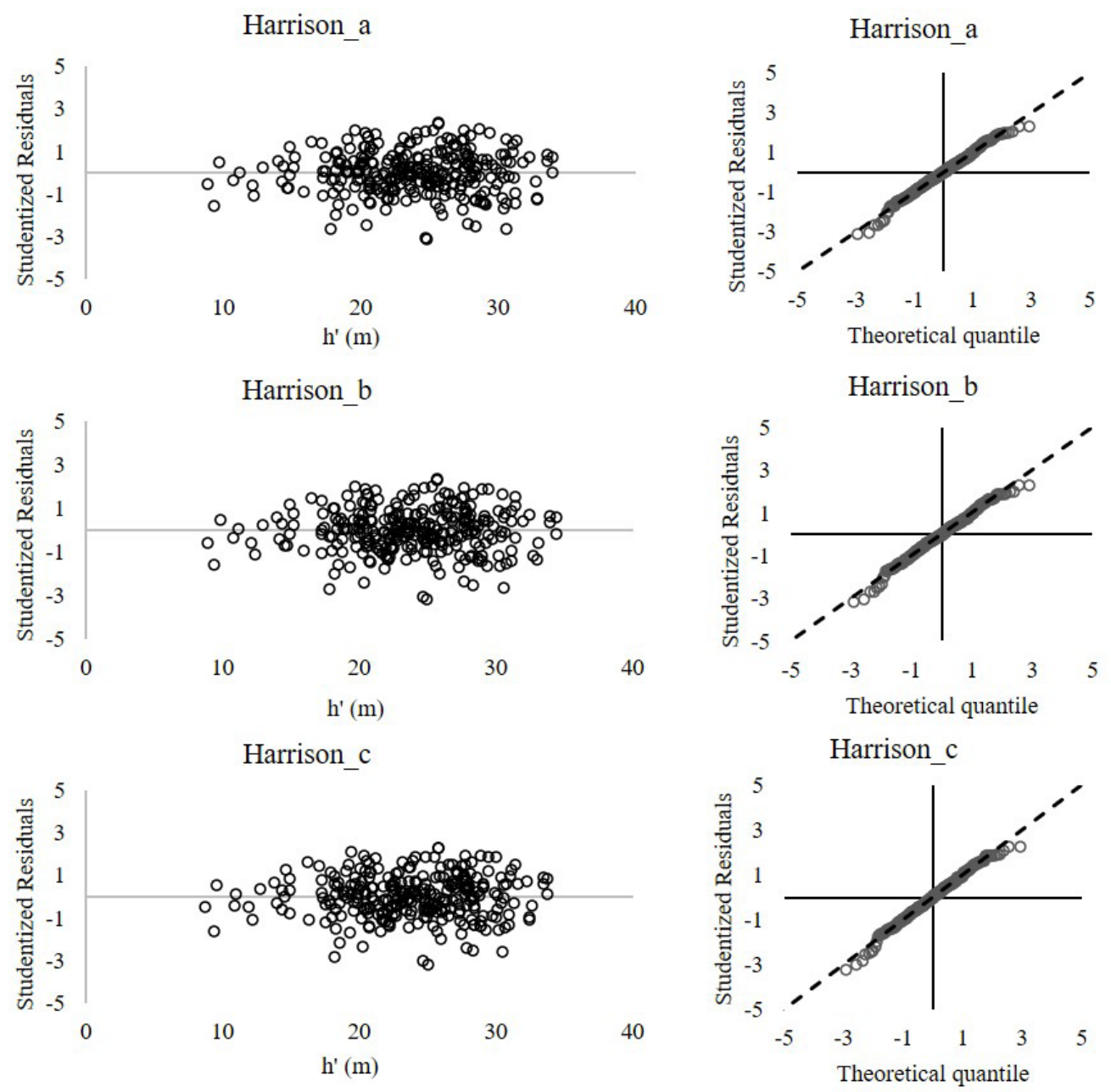

Figure 2. Analysis of studentized residuals for different versions of Harrison et al. (1986) equation, with the parameters expressed as linear function of stand variables, to represent height-diameter relationship of Eucalyptus benthamii Maiden et Cambage. 

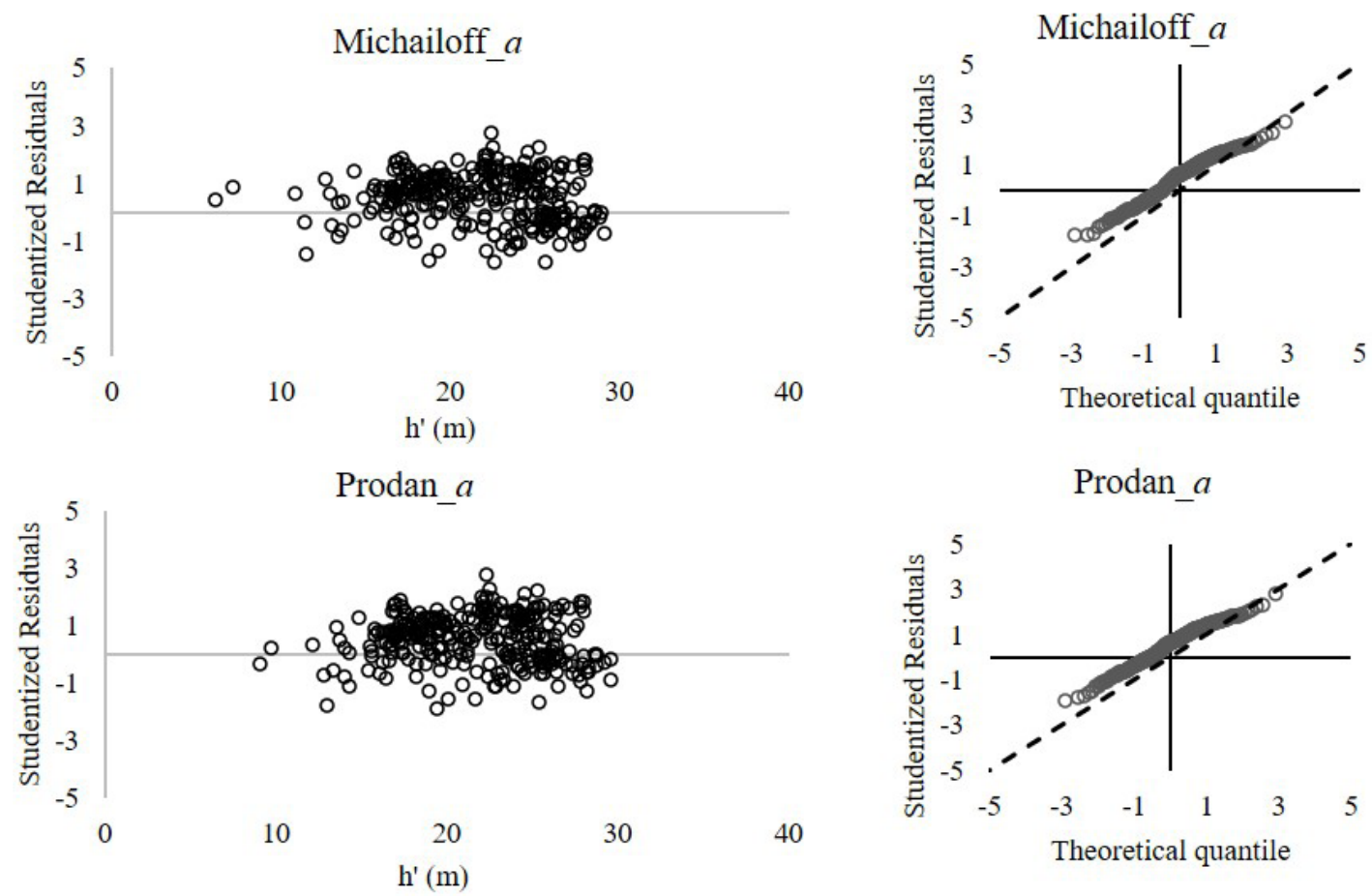

\section{Prodan_a}
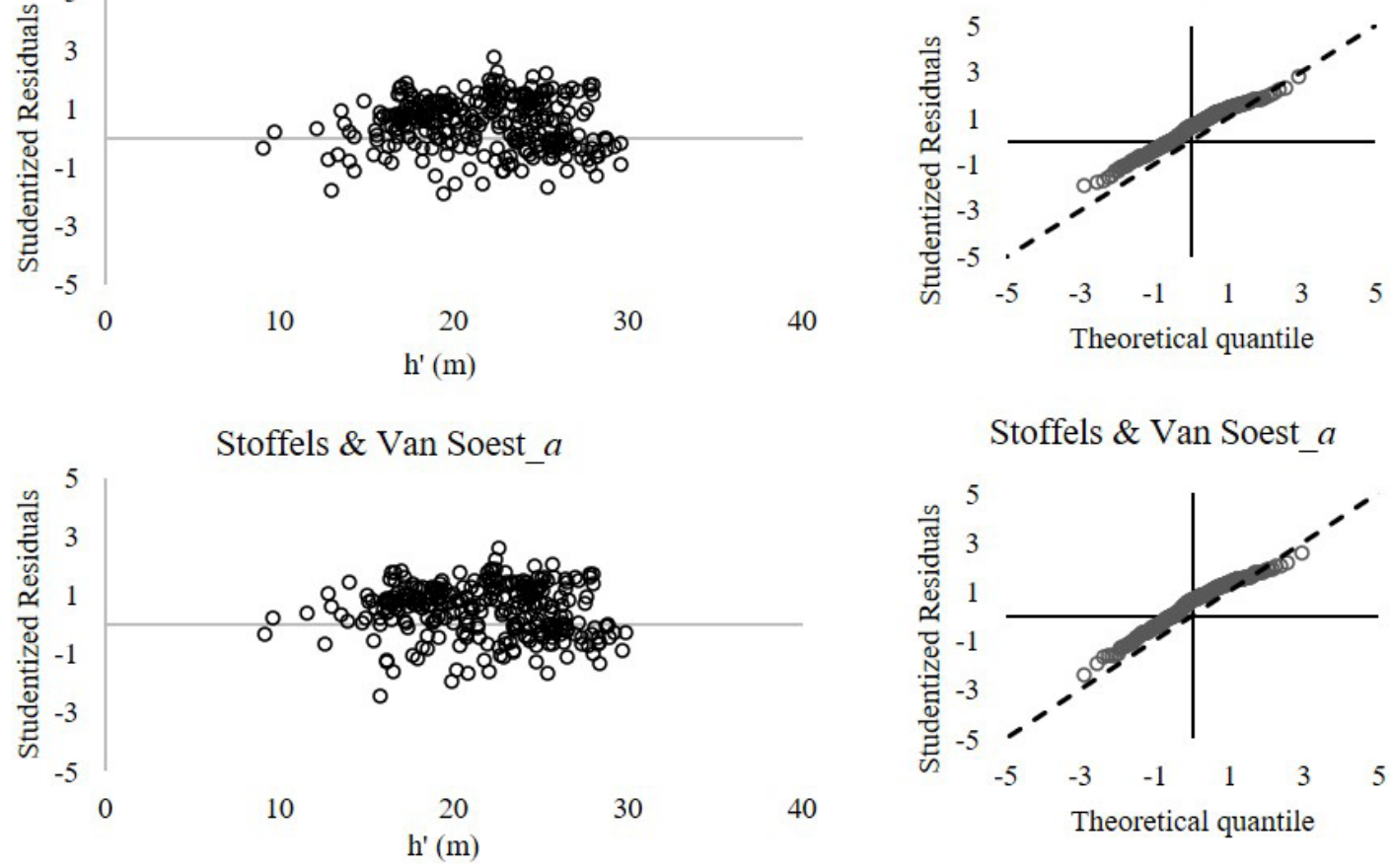

\section{Stoffels \& Van Soest_ $a$}

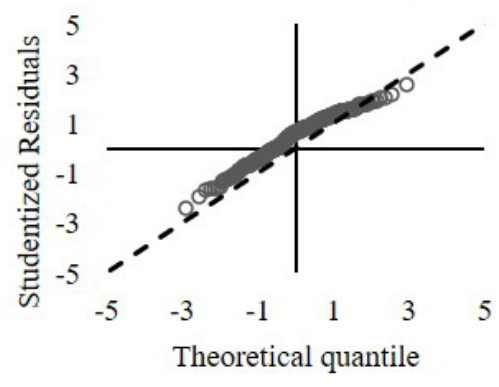

Figure 3. Analysis of studentized residuals for Michailoff, Prodan and Stoffels \& Van Soest equations, with the parameters expressed as linear function of stand variables, to represent height-diameter relationship of Eucalyptus benthamii Maiden et Cambage.

Table 3. Validation statistics of the height-diameter equations for Eucalyptus benthamii Maiden et Cambage, in the municipality of Irani - SC.

\begin{tabular}{lccccc}
\multicolumn{1}{c}{ Equation } & EM & MDPRESS & MADPRESS & P5 & P95 \\
\hline Harrison_a & 0,8633 & $-0,0058$ & 1,5225 & $-3,45$ & 3,19 \\
\hline Harrison_b & 0,8755 & $-0,0071$ & 1,4809 & $-3,02$ & 2,99 \\
\hline Harrison_c & 0,8940 & $-0,0081$ & 1,3470 & $-2,78$ & 2,50 \\
Michailoff_a & 0,4359 & 1,9059 & 3,2425 & $-3,81$ & 6,95 \\
\hline Prodan_a & 0,4661 & 1,8920 & 3,0840 & $-3,27$ & 7,00 \\
$\begin{array}{l}\text { Stoffels e Van } \\
\text { Soest_a }\end{array}$ & 0,4354 & 1,9155 & 3,1978 & $-3,33$ & 7,19
\end{tabular}

Where: $\mathrm{EM}=$ modeling efficiency; $\mathrm{MAD}_{\mathrm{PRESS}}=$ average of the PRESS differences; $\mathrm{MAD}_{\mathrm{PRESS}}=$ average of the PRESS absolute differences; $\mathrm{P} 5=5 \%$ percentile value of the PRESS residuals; P95 = 95\% percentile value of the PRESS residuals.
According to the selection statistics (Table 2), analysis of studentized residuals (Figures 2 and 3 ) and validation statistics (Table 3), the most appropriate equation to represent the height-diameter relationship of Eucalyptus benthamii stands was Harrison_c (Equation 12). As occurred in this study, Téo et al. (2017) selected the Harrison et al. (1986) model adjusted with its parameter "c" expressed as a linear function of stand variables to represent the height-diameter relationship of Pinus taeda stands in the West region of Santa Catarina State. Soares \& Tomé (2002) also selected the Harrison et al. (1986) model, however with the parameter "a" expressed as a linear combination of stand variables, to represent the hypsometric relationship of Eucalyptus globulus stands in Portugal. 
The Harrison_c function, chosen to estimate total height (h) of Eucalyptus benthamii, is given by the equation 12 .

$$
h=1,3+\left\{h_{d o m}\left[1+0,727383 e^{\left(0,016398 h_{d o m}\right)}\right]\left[1-e^{\left(-c\left(\frac{d}{h_{d o m}}\right)\right)}\right]\right\}
$$

(Equation 12)

where: $c=0,620953+0,088471 t+0,011543 d_{d o m}-0,012183 G$; $\mathrm{h}=$ total height $(\mathrm{m}) ; \mathrm{d}=$ diameter at breast height $(\mathrm{cm})$; $\mathrm{h}_{\text {dom }}=$ dominant height of the sample plot $(\mathrm{m}) ; \mathrm{t}=$ age of the forest stand (years); $d_{\text {dom }}=$ dominant diameter $(\mathrm{cm})$; $\mathrm{G}=$ basal area of the sample plot $\left(\mathrm{m}^{2} \cdot \mathrm{ha}^{-}\right) ; \mathrm{e}=$ Euler's constant $(2,718281829 \ldots)$.

The parameter " $\mathrm{c}$ " is also known as rate parameter of the Harrison et al. (1986) model, which guarantees that the height increase rate is smaller for the greatest diameter at breast height (d). This parameter " $c$ " was expressed as a linear combination of age $(t)$, dominant diameter (ddom) and basal area of the sample plot (G). These formulation and adjustment model attributes allow portraying the differences in height-diameter relationship of Eucalyptus benthamii, under the effect of these several stand variables, as well as, ensure more general applicability to the equation.

The hypsometric relationship of Eucalyptus benthamii represented by the Equation 12, with increasing age, moves to the right and rises of level following the diameter and height growth (Figure 4). The same pattern was found by Araújo et al. (2012), for the hypsometric relationship of Eremanthus erythropappus Mac Leish stands, with ages ranging from 4 to 8 years.

Concerning the stand density, the lower the densities, the higher the position of the height-diameter curves of Eucalyptus benthamii predicted by the Equation 12 (Figure 4). Similar results were found by Bartoszeck et al. (2004) when evaluating Mimosa scabrella Benth. stands, in municipality of Curitiba - PR, the height-diameter curves are located at a higher level for the lower density stands, at age of 7,5 years. However, Bartoszeck et al. (2004) reported for the others ages they evaluated, that the height-diameter curves were at the same level and with similar slope, so they concluded that the stand density did not affect the hypsometric relationship of Mimosa scabrella.
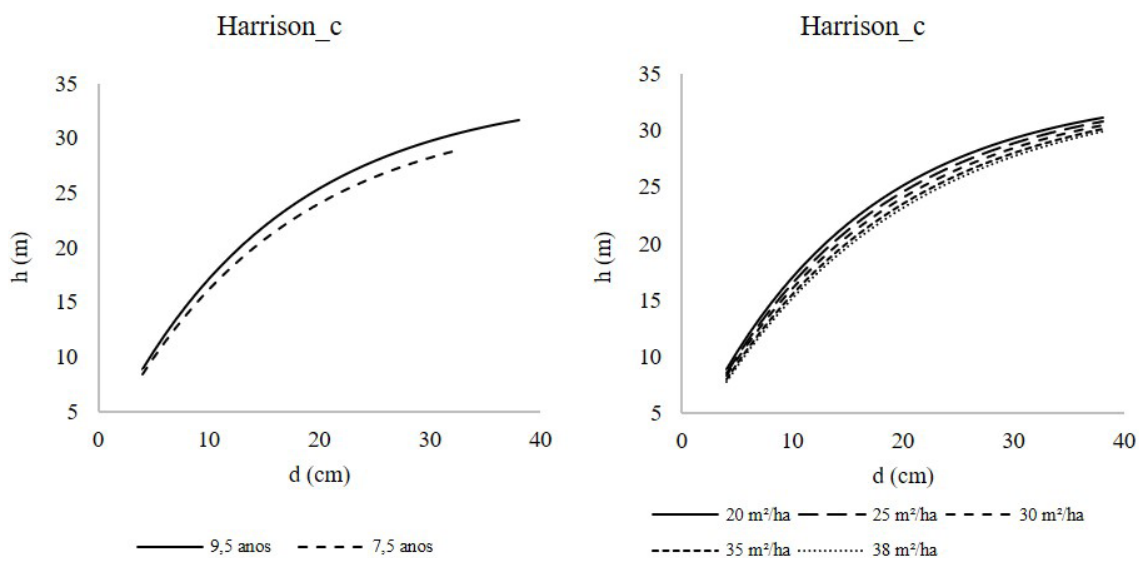

Figure 4. Age and density effect on hypsometric relationship curves, represented by Harrison et al. (1986) model with the parameter "c" expressed as linear function of stand variables of Eucalyptus benthamii Maiden et Cambage stands, in the municipality of Irani - SC.

\section{CONCLUSIONS}

The Harrison et al. (1986) function, adjusted with the parameter " $c$ " expressed as a linear combination of age $(t)$, dominant diameter $\left(\mathrm{d}_{\mathrm{dom}}\right)$ and basal area of the sample plot $(\mathrm{G})$ was the most appropriate to represent the height-diameter curves of Eucalyptus benthamii stands, in the municipality of Irani - SC. The formulation and adjustment characteristics of the modeling procedure used in this study allow the representation of the height-diameter relationship of stands with different ages and stand densities.
The height-diameter curves move to the right and level up with increasing age, because of the diameter and height growth. The lower the stand density, the higher the level of the height-diameter curves, suggesting that trees with equal diameters are taller in the lower density forest stands.

\section{ACKNOWLEDGEMENTS}

The authors would like to thank the University of Western Santa Catarina (UNOESC), Santa Catarina University Scholarship Program (UNIEDU) and Jaquelei Thibes de Barros for reviewing the text. 


\section{SUBMISSION STATUS}

Received: 20 June 2018

Accepted: 23 Oct. 2018

Associate editor: Emanuel José Gomes de Araújo

\section{CORRESPONDENCE TO}

\section{Tainá Carnera da Silva}

Universidade do Oeste de Santa Catarina, Rua: Dirceu Giordani,

696, Jardim Tarumã, Xanrere, Santa Catarina, Brasil

e-mail: tainallemos@gmail.com

\section{REFERENCES}

Alvares CA, Stape JL, Gonçalves JLM, Sentelhas PC, Sparovek G. Köppen's climate classification map for Brazil. Meteorologische Zeitschrift. 2013; 22 (6): 711-728.

Alves ICN, Gomide JL, Colodette JL, Silva HD. Caracterização tecnológica da madeira de Eucalyptus benthamii para produção de celulose kraft. Ciência Florestal, 2011; 21(1): 67-174.

Araújo EJG, Pelissari AL, David HC, Scolforo JRS, Netto SP, Morais VA. Relação hipsométrica para candeia (Eremanthus erythropappus) com diferentes espaçamentos de plantio em Minas Gerais, Brasil. Pesquisa Florestal Brasileira, 2012; 32 (71): 257-268.

Azevedo GB, Sousa GT O, Silva HF, Barreto PAB, Novaes AB. Seleção de modelos hipsométricos para quatro espécies florestais nativas em plantio misto no Planalto da Conquista na Bahia. Enciclopédia Biosfera, 2011; 7 (1): 1- 13.

Bartoszeck ACPS, Machado AS, Figueiredo AF, Oliveira EB. Dinâmica da relação hipsométrica em função da idade, do sítio e da densidade inicial de povoamentos de bracatinga da região metropolitana de Curitiba, Paraná. Revista Árvore, 2004; 28 (4): 517-533. http://dx.doi. org/10.1590/S0100-67622004000400006.

Costa EA, Finger CAG, Cunha TA. Infuência da posição sociológica na relação hipsométrica de Araucaria angustifolia. Revista de Ciências Agrárias, 2014; 9 (1): 110-116.

Donadoni AX, Pelissari AL, Drescher R, Rosa GD. Relação hipsométrica para Pinus caribaea var. hondurensis e Pinus tecunumanii em povoamento homogêneo no Estado de Rondônia. Ciência Rural. 2010; 40 (12): 2499- 2504.

Draper NR, Smith H. Applied regression analysis. 3 ed. New York: John Wiley and Sons, 1998; 706.

EMBRAPA - EMPRESA BRASILEIRA DE PESQUISA AGROPECUÁRIA. (Rio de Janeiro, RJ). Mapa de solos do Brasil. Rio de Janeiro, 2011. Mapa. Escala: 1:5.000.00.

Figueiredo Filho A, Dias AN, Kohler SV, Verussa AA, Chiquetto AL. Evolution of the hypsometric relationship in Araucaria angustifolia plantations in the mid-south region of Paraná State. Cerne, 2010; 16 (3): 347-357.

Harrison WC, Burk TE, Beck DE. Individual tree basal area increments and total height equations for appalachian mixed hardwoods after thinning. Southern Journal of Applied Forestry, 1986; 10 (2): 99-104.
Hess AF, Braz EM, Thaines F, Mattos PP. Ajuste de relação hipsométrica para espécies da Floresta Amazônica. Ambiência, 2014; 10 (1): 21-29. ISSN 1808 - 0251.

Huber, PJ. Robust estimation of a location parameter. The annals of mathematical statistics, Beachwood, 1964; 35 (1): 73-101.

Leduc D, Goelz J. A height-diameter curve for longleaf pine plantations in the gulf coastal plain. Southern Journal of Applied Forestry, 2009; 33 (4): 164-170.

Machado SA, Accioly Y, Nascimento RGM, Silva LCR, Cardozo CC. Influência do comprimento de copa na relação hipsométrica de Araucaria angustifolia. Pesquisa Florestal Brasileira, 2015; 35 (83): 343-351.

Machado SA, Barros DA, Scolforo, JRS, Arcebi Junior FW. The effects of successive thinning's on the hypsometric function for Pinus oocarpa stands. Revista Floresta, 2011; 41 (2): 397- 406.

Machado SA, Figueiredo Filho A. Dendrometria. 2. ed. Guarapuava: UNICENTRO, 2014.

Martins APM, Carvalho DE, Franceschi F, Gallo JC, Vuaden E, Weber VP. Relação hipsométrica para Pinus elliottii Engelm. em diferentes posições sociológicas em Dois Vizinhos, PR. Scientia Agraria Paranaensis, 2016; 15 (2): 158-163.

Montgomery DC, Peck EA, Vining GG. Introduction to linear regression analysis. 4 ed. New York: John Wiley and Sons, 2006; 612.

Müller, BV, Rocha, MP, Cunha, AB, Kltzke RJ, Nicolleti MF, Avaliação das principais propriedades físicas e mecânicas da madeira de Eucalyptus benthamii Maiden et Cambage. Floresta e Ambiente, 2014; 21 (4): 535-542. ISSN 2179-8087.

Myers, RH. Classical and modern regression with applications. Boston: Duxbury Press, 1986: 359.

Oliveira FGRB, Sousa GTO, Azevedo GB, Barreto PAB. Desempenho de modelos hipsométricos para um povoamento de Eucalyptus urophylla no município de Jaguaquara, Bahia. Enciclopédia Biosfera, 2011; 7 (13): 331-338.

Parresol, BR. Modeling multiplicative error variance: an example predicting tree diameter from stump dimensions in bald cypress. Forest Science, 1993; 39 (4): 670-679.

Paulo JA, Tomé J, Tomé M. Nonlinear fixed and random generalized height-diameter models for Portuguese cork oak stands. Forest Science, 2011; 68 (1): 295-309.

Paulo JA, Tomé M. An individual tree growth model for juvenile cork oak stands in southern Portugal. Silva Lusitana, Lisboa, 2009; 17 (1): 27-38.

Retslaff FAS, Figueiredo Filho A, Dias AN, Bernett LG, Figura MA. Curvas de sítio e relações hipsométricas para Eucalyptus grandis na região do Campos Gerais, Paraná. Cerne, 2015; 21 (2): 219-225.

Rufino RF, Miguel EP, Santos GA, Santos TEB, Souza F. Ajuste de modelos hipsométricos para um povoamento de eucaliptos conduzido sobre o sistema de rebrota. Enciclopédia Biosfera, 2010; 6 (10): 1-10.

Sanquetta CR, Corte APD, Roglin A, Pimentel A. Relações diâmetroaltura para espécies lenhosas em um fragmento de Foresta Ombrófila Mista no Sul do Paraná. Iheringia, 2013; 68 (1): 103-114. 
Silva RS, Vendruscolo DGS, Rocha JRM, Chaves AGS, Souza HS, Motta AS. Desempenho silvicultural de Tectona grandis L. f. em diferentes espaçamentos em Cáceres, MT. Floresta e Ambiente, 2016; 23 (3): 397-405. ISSN 2179-8087.

Soares $\mathrm{P}$, Tomé $\mathrm{M}$. Height-diameter equation for first rotation eucalypt plantations in Portugal. Forest Ecology and Management, 2002; 166 (1-3): 99-109.

Téo SJ, Machado SA, Filho AF, Tomé M. General height-diameter equation with biological attributes for Pinus taeda L. stands. Cerne, 2017; 23 (4): 403-411. ISSN 0104-7760.
Tomé M, Ribeiro F, Faias S. Relação hipsométrica geral para Eucalyptus globulus Labill. em Portugal. Silva Lusitana, Lisboa, 2007; 15 (1): 41-55.

Vendruscolo DGS, Chaves AGS, Silva RS, Souza HS, Medeiros RA, Motta AS et al. Identidade em modelos hipsométricos para Tectona grandis com diferentes espaçamentos em Cáceres-MT. Nativa, 2015; 3 (1): 44-49.

Wilson, FG. Control of growing stock in even-aged stands of conifers. Journal of Forestry, Bethesda, 1951; 49 (10): 692-695. 